\title{
The Teaching Reform of E-commerce Logistics Course based on the Production-education Integration
}

\author{
Ling Feng \\ School of Information Science and Technology \\ Taishan University \\ Taian, China \\ fengxinxin@163.com
}

\begin{abstract}
E-commerce logistics course is the professional and core courses of E-commerce major. In real teaching, due to many reasons, many problems emerged, such as students' enthusiasm for learning is not high, the learning effect is not good, and students are not equipped with practical ability. In this situation, Based on the production-education integration, combined with the capacity demand of enterprise logistics position, depending on project training, skill competition and enterprise practice, this paper puts forward some reasonable proposals on the teaching content and teaching method in order to cultivate the e-commerce logistics compound talents.
\end{abstract}

Keywords-E-commerce Logistics; Teaching Reform; Practical Teaching; Production-education Integration

\section{INTRODUCTION}

With the rapid development of e-commerce, the role of logistics in e-commerce is becoming more and more obvious, and the demand for e-commerce logistics talents is increasing. It is also important to study e-commerce logistics course of e-commerce major. E-commerce logistics is a comprehensive discipline, and involves two professional fields: e-commerce and logistics, mainly describes the logistics in the electronic commerce environment. The leading courses of logistics include introduction to e-commerce and management. Only if we learn the important core course of e-commerce logistics, can we meet the modern logistics industry which is developing vigorously in the current e-commerce environment. However, in real teaching, there are many problems such as unstandardized teaching content, single teaching method and weak practice teaching, which lead to students' interest in learning is not high and cannot meet the needs of enterprises for logistics talents. Based on the production-education integration and combined the ability demand of enterprise logistics position, this paper explores the teaching contents and teaching methods of e-commerce logistics course in e-commerce major.

\section{REFORM OF TEACHING CONTENT BASED ON THE PRODUCTION-EDUCATION INTEGRATION}

The production-education integration is the deep cooperation between enterprise and school education. The enterprise participates in the professional personnel training mode, the curriculum system reform and the teacher team construction. The school puts enterprise's needs as the starting point of talent cultivation, and sets the teaching and practice content according to the specific work position and workflow of the enterprise. The students completed the basic knowledge theory and part practice teaching in the school, and completed the position practice and specific project training in the enterprise. The school and the enterprise jointly develop the students to become the operation ability strong, the knowledge structure broad and the comprehensive quality high talented persons, who are really needed by the enterprise [1].

In order to make the course content close to the enterprise's demand for e-commerce logistics talents, the course group teachers conduct in-depth business surveys and communicate with business executives and logistics management experts. They have in-depth analysis of the logistics related positions of e-commerce enterprises, and have reintegrated the course content on the basis of the professional qualification criteria of the logistics manager enacted by the Ministry of Human Resources and Social Security. According to the requirements of the ability of enterprises for logistics talent, we divide the course content into three modules: the basic knowledge module in order to improve the professional knowledge, the skill application module in order to develop professional capacity and the quality development module in order to cultivate enterprise management ability [2]. Each module is divided into multiple learning tasks. The detailed arrangement is shown in table 1.

TABLE I. CONTENT OF COURSES

\begin{tabular}{|l|l|l|}
\hline Module name & \multicolumn{1}{|c|}{ learning tasks } & Teaching form \\
\hline \multirow{2}{*}{$\begin{array}{l}\text { Basic } \\
\text { knowledge } \\
\text { module }\end{array}$} & Task 1: Overview of modern logistics & \multirow{2}{*}{$\begin{array}{l}\text { Theoretical } \\
\text { teaching }\end{array}$} \\
\cline { 2 - 3 } & Task 2: The relationship between e-commerce and logistics & \\
\cline { 2 - 3 }
\end{tabular}


TABLE I. CONTENT OF COURSES (CONT)

\begin{tabular}{|c|c|c|}
\hline \multirow{5}{*}{$\begin{array}{l}\text { Basic } \\
\text { knowledge } \\
\text { module }\end{array}$} & Task 4: Understanding of e-commerce logistics technology & \multirow{5}{*}{$\begin{array}{l}\text { Theoretical } \\
\text { teaching }\end{array}$} \\
\hline & Task 5: Understanding of the functional elements of e-commerce logistics & \\
\hline & Task 6:Understanding of production logistics management in e-commerce environment & \\
\hline & Task 7: Understanding of logistics business management & \\
\hline & Task 8: Understanding of supply chain management & \\
\hline \multirow{7}{*}{$\begin{array}{l}\text { Skill } \\
\text { application } \\
\text { module }\end{array}$} & $\begin{array}{l}\text { Task 1:The transformation of traditional logistics enterprises in } \\
\text { e-commerce environment }\end{array}$ & \multirow{7}{*}{$\begin{array}{l}\text { Campus } \\
\text { training + } \\
\text { Enterprise } \\
\text { Investigation }\end{array}$} \\
\hline & Task 2: Enterprise logistics mode choice & \\
\hline & Task 3: Application of e-commerce logistics information technology & \\
\hline & Task 4: Purchasing decision and organization in e-commerce environment & \\
\hline & Task 5: Stock design and control in e-commerce environment & \\
\hline & Task 6: Transportation mode selection, stowage and route planning & \\
\hline & Task 7: Compiling distribution operation plan and optimizing distribution route & \\
\hline \multirow{6}{*}{$\begin{array}{l}\text { Quality } \\
\text { development } \\
\text { module }\end{array}$} & Task 1: Formulation and implementation of production logistics plan & \multirow{5}{*}{$\begin{array}{l}\text { Campus } \\
\text { training + } \\
\text { Enterprise } \\
\text { Investigation }\end{array}$} \\
\hline & Task 2:Logistics business management control & \\
\hline & Task 3:Use of warehouse and transportation management software & \\
\hline & Task 4: Logistics management information system construction & \\
\hline & Task 5: Supply chain management design and Implementation & \\
\hline & Task 6: Comprehensive training of e-commerce logistics business process & $\begin{array}{l}\text { Enterprise } \\
\text { practice }\end{array}$ \\
\hline
\end{tabular}

\section{REFORM OF TEACHING METHODS BASED ON THE PRODUCTION-EDUCATION INTEGRATION}

E-commerce logistics is a very practical course. If we use traditional teaching methods to preach the textbooks, it will make the teaching which is vivid and interesting become very boring. According to the training objectives and the characteristics of this course, we adopt diversified teaching methods based on the Production-education integration, including multimedia, experience, case, visit and practice teaching methods to enable students to produce a vivid perceptual knowledge of e-commerce logistics, cultivating the practical ability of students, improve the students' learning interest and learning effect, achieve to cultivate applied talents for teaching purpose.

\section{A. Multimedia Teaching Method}

Through the network access to teaching resources, such as cases, pictures, flow charts and videos, enrich the content of teaching. Using multimedia teaching methods to demonstrate these content, let students establish perceptual knowledge of learning objects, and lay a foundation for future knowledge learning and practice. Such as: demonstration of software operation process, demonstration of modern logistics facilities, equipment and work process, demonstration bar code production and application. In the demonstration at the same time, combined with the necessary explanation of teachers, we received good teaching results. Especially the application of video based on the content and scene of enterprise's real work make the practice teaching transferred from the classroom to the real job through multimedia technology, solves the problems that some students are difficult to operate in real operation, and opens up the students' professional field of vision.

\section{B. Experiential Teaching Method}

This course uses experience matching software, and the students access the experimental teaching simulation platform through browser, and drill the operation flow of various software. Students are familiar with the flow of logistics operations at the same time, and lay the foundation for the future operation of real software. This method of teaching improves the students' enthusiasm for learning and obtains good teaching results.

\section{Case Teaching Method}

Teaching content is divided into a number of learning tasks, through the task of explanation, analysis and discussion, the students can master the relevant professional skills, knowledge and theory. Learning tasks are combined with specific real cases of enterprises, which can be provided by the teacher or can be collected by the students online. There are two kinds of implementation methods, one is to explain the basic theory, combined with case analysis, guide students to clearly understand the knowledge involved in the case, the case is integrated with the theoretical knowledge, stimulate students' interest in learning, enhance students understanding, and cultivate students' thinking ability. The two is to organize students to use their knowledge to discuss and analyze cases, find ways to solve problems, so as to improve students' ability to analyze and solve problems.

\section{Visiting Teaching Method}

The school regularly organizes students to visit logistics companies or e-commerce enterprises, and explains the responsibilities of the logistics and the functions of the logistics process by the enterprise professionals. Through this method of teaching, let students establish perceptual knowledge; understand what logistics is, what should be learned, and how to lay a good foundation for future work. This kind of teaching method is very popular with students. Every time they come back, the students are full of confidence. They discuss it actively and write a visit report under the guidance of the teacher. They describe their feelings and plans for the future. 


\section{E. Practice Teaching Method}

All of the above teaching methods are the basis for practical teaching; the purpose of learning is to practice. Practical teaching includes campus training and enterprise practice. Campus training is mainly through the school laboratory to complete training tasks. Enterprise practice is mainly to sign practice agreements with many enterprises, after students completing the course of theoretical teaching and campus training, they can go to the enterprise for one to two weeks of enterprise practice. Through the practice teaching method, the student applies the knowledge which the school has learned to the enterprise concrete work, can grasp the knowledge and the application skill, and can lay the good foundation for the later work. After the student's practice, they need to write a practice report to sum up their achievements and shortcomings.

\section{OTHER MEASURES BASED ON THE PRODUCTION-EDUCATION INTEGRATION}

In order to promote the practice teaching of the e-commerce logistics course, the following measures are adopted in the actual teaching.

\section{A. Encourage Students to enter Competition}

On the basis of the combination of classroom teaching, the competition of college students can stimulate students' ability to combine theory with practice and work independently. Through practice, they can find problems and solve problems, so as to enhance their confidence in their study and work. Through competition, students can not only master theoretical knowledge, but also enhance their application, operation and practical ability, and lay a good foundation for practice, training and work in enterprises.

\section{B. Promoting the Training of "Double Qualified" Teachers}

In order to improve the level of teachers, especially to improve the quality of practical teaching, teachers are encouraged to go deep into the enterprise to understand the specific professional skills required by the enterprise and the logistics jobs, and to participate in the practice teaching, training and assessment of the enterprise organizations; The frontline staff of enterprise logistics or enterprise logistics experts are hired as part time teachers of the course, they teach the students about the requirements and skills of logistics posts in the enterprise, and carry out training programs related to the courses at the end of the semester. The teachers and the high level of part-time teachers are closely integrated, and then form a team of "double qualified" teachers. It ensures the normal operation of the production-education integration and the implementation of practical teaching, so as to promote the teaching quality and teaching effect [3].

\section{V.CONCLUSIONS}

Practice has proved that, the teaching reform of e-commerce logistics course based on the production-education integration re integration the content of teaching, adopt diversified teaching methods and teaching measures, can be very good to cultivate students' interest in learning, enhance students' awareness of innovation, improve the students' practical ability, and achieved good teaching effect in the teaching practice process, and offer the reference for the practice teaching reform of other professional courses of e-commerce major.

\section{REFERENCES}

[1] Qin Fengmei. The teaching evaluation system of e-commerce practice and training based on the production-education integration, J career space time, 2015 (5): 32-34, 44 .

[2] Meng Zeyun, Huang Yajing. Exploration of the curriculum reform of e-commerce logistics management based on the working process, J e-commerce, 2011 (11): 87-88, 90 .

[3] pan Hua. Exploration of e-commerce talents training based on the integration of production and education, platform support, $\mathrm{J}$ China management information, 2016 (19): 224-227. 